The $5^{\text {th }}$ International Conference on Family Business and Entrepreneurship

\title{
THE EFFECT OF BUSINESS ECOSYSTEM AND GOVERNMENT REGULATION TOWARD BUSINESS AGILITY: THE ROLE MEDIATING OF BUSINESS MODEL INNOVATION IN SMES
}

\author{
Ervina Waty ${ }^{1 *}$, Idris Gautama So ${ }^{2}$, Richardus Eko Indrajit ${ }^{3}$, \\ Sri Bramantoro Abdinagoro ${ }^{4}$ \\ ${ }^{1,2,4}$ Bina Nusantara University \\ ${ }^{3}$ Pradita University \\ Corresponding author: ervina20_2000@yahoo.com
}

\begin{abstract}
SMEs have become the backbone of the Indonesian economy which is faced with various situations and conditions. The increasingly competitive business environment forces SMEs to be able to maintain their existence. This effort can be realized by developing a good business ecosystem with the support of government regulations. In addition, business model innovation is also worth considering the changing needs, wants, and demands of customers. This study aims to examine the effect of ecosystem business and government regulation toward business agility mediated by business model innovation. This study involved 100 SME culinary in Bali, Bandung, Surabaya, Yogyakarta, Semarang, Solo dan Jakarta which are selected using probability sampling technique. Data is obtained by distributing questionnaires to respondents through G-Form. The collected data is then analyzed using Path analysis assisted by the Smart PLS application. The result shows that the business ecosystem and government regulation and business model innovation have a significant positive effect toward business agility. Business model innovation can mediate the relationship of the business ecosystem to business agility and the relationship of government regulation to business agility. Business model innovation is influenced by Business ecosystem and Government Regulation by 68.8\%, business ecosystem, Government Regulation and business model innovation affects business agility by 61.6\%. Researchers who want to conduct research on similar topics can add other independent and dependent variables so that the results obtained are more coherent.
\end{abstract}

Keywords: Business Ecosystem, Government Regulation, Business Model Innovation, and Business Agility

\section{Introduction}

The development of an increasingly rapid era makes business organizations occupy a major position (Putri Rusadi \& Benuf, 2020). One that has been widely discussed is the role of SMEs as the backbone of the economy in Indonesia. Data from the Ministry of Cooperatives and Small and Medium Enterprises in 2017 shows that the contribution of SMEs to Gross Domestic Product is $62.57 \%$ or a value of Rp7,005,950 billion (Kementerian Koperasi dan Usaha Kecil Menengah, 2017). The total population of Indonesian SMEs in 2017 reached 60 million business units with employment of $97 \%$ of the total national workforce. Currently, there are at least 60 million SMEs in Indonesia. Data from the Ministry of Cooperatives and Small and Medium Enterprises states that the SMEs segment can absorb 96.8\% of the national workforce. Meanwhile, the large business segment was only able to absorb the remaining 3.2\%. This data shows that SMEs have an important role in Indonesia's economic development (Kementrian KUKM, 2021) 
Currently, the business world is in a transition period from the industrial revolution era to the information and communication revolution triggered by technological changes (Lytvynenko \& Panasiuk, 2020). Being in the era of globalization, SMEs executants face a challenging and increasingly competitive business environment. The environmental conditions faced by SMEs are very complex. Therefore, to win the competition, companies must have the ability to compete by responding to changes that occur in the market more quickly, creating products with better quality, and carrying out production processes at lower costs (faster, better, cheaper). It can be done with the support of business agility. Business agility refers to certain qualities that enable SMEs to respond quickly to changes in what is happening while staying to focus on the planned goals. Innovation of the business model used is one of the determinants of the success of the agility business carried out by SMEs (Shakeel, Mardani, Chofreh, Goni, \& Klemeš, 2020). Things that are done to be able to create a sustainable business, survive from time to time, and create a successful business can even generate large profits.

Efforts to improve existing business processes in SMEs businesses require further analysis of business models that are relevant to the current situation and conditions; considering that market conditions integrated with technology lead to increasingly volatile conditions. It also has an impact on unstable SMEs profits; thus, it does not reflect a good business process. If SMEs do not immediately improve, the threat from competitors who have innovated can threaten the sustainability of existing businesses considering that many SMES are still operating conventionally (Wulansari, Ranihusna, \& Wijaya, 2020). The division of target segments, target markets, and how SMEs can position themselves in the community are several keys to success in the future (Yacob, Erida, Machpuddin, \& Alamsyah, 2021). The implementation of the innovation business model carried out certainly adjusts to the business ecosystem that is being faced (Geissdoerfer, Vladimirova, \& Evans, 2018). Business ecosystem can create new values to compete in economic sectors (Cohendet, Simon, \& Mehouachi, 2020). The business ecosystem is a very big thing and needs to be targeted specifically because it will give confidence to SMEs executants. With the implementation that occurs with the importance of the business ecosystem, there will be something new and can be changed by SMEs executants (Hsieh, Lin, Lu, \& Rong, 2017). In a business ecosystem, the need for organizations or actors is involved in the business environment. Successful organizations have unique behaviors when they become the best in their industry (Rong, Patton, \& Chen, 2018).

In addition to the managerial factor of SMEs, the government's encouragement for the existence of SMEs is also something to be reckoned with (Gui et al., 2020). Improving SMEs regulations is one of the substances prioritized for discussion in the Job Creation Law (Berliandaldo, Fasa, Kholiyah, Chodiq, \& Hendrix, 2020). According to (Lorenzo, Kawalek, \& Wharton, 2018) the existing regulation is one of the triggering factors for business innovation. The government pays great attention to the development of SMEs in order to survive in the global crisis (Ratnawati, 2020). Various initiatives are attempted by the government through the State Ministry of Cooperatives and Small and Medium Enterprises so that more individuals are willing to pursue the entrepreneurship sector in the form of establishing SMEs (Kementrian KUKM, 2021).

According to (Purwaningsih \& Suhaeri, 2019) one of the government's supports for SMEs is the provision of business capital. Business capital is absolutely necessary to carry out business activities. Therefore, a certain amount of funds is needed as a basis for financial measures for the efforts carried out. In 2020, SMEs who receive KUR are given an additional interest subsidy of up to $6 \%$; thus, in AprilDecember 2020, the interest rate will be $0 \%$. In addition, the government also established a super micro KUR scheme aimed at housewives who build micro-scale businesses (Malelak, Kellen, \& Rozari, 2020). In 2021, the government has set an extension of interest at 3\%, a postponement of principal installments and relaxation of the KUR policy in the form of an extension of time and the addition of the KUR ceiling to 253 trillion. The capital obtained by SMEs executants affects how the business model will be implemented. The capital factor is the key point of any business where large capital will affect the large variety of products and labor. The availability of product variations in sufficient, sustainable, and affordable prices will facilitate production which in turn will increase sales results and can increase the amount of operating profit earned by entrepreneurs (Saxena, 2019).

The ease of doing business has been realized by the government through improving regulations in various sectors, from starting a business, protecting minority shareholders, speeding up service time standards, innovating, socializing, to improving services through the online system. According to (Koçu, 2018) regulation government can affect business agility. This study aims to examine the effect of ecosystem business and government regulation toward business agility mediated by business model innovation. 


\section{Literature Review}

\section{Business Ecosystem}

The concept of a business ecosystem consists of all the individuals, organizations, government involvements, and the regulations in which the business interacts including consumers, competitors, media, etc (Ferreira \& Teixeira, 2019). A business or company must be able to develop its own business ecosystem in order to survive in a fairly competitive business competition (Ramezani \& Camarinha-Matos, 2020). The importance of building a business ecosystem is the key to success in a business or organization (Rezac, 2020). The business ecosystem creates relationships between business executants; and it is in accordance with the concept of a social network which is useful for knowing the relationships of each executant.

According to (Rong, Lin, et al., 2018), a company should see their business as an interdependent part of a multi-stakeholder community whose interests are an integral part of business success. In this view, the company can be seen as a system of long-term cooperative relationships between the affected parties. It includes company managers, employees, customers, clients, investors, suppliers, cities, states, and countries where the company is located and sells goods, services, and even future generations of stakeholders. Stakeholder influence generates pressure for organizations to behave in an ethically and environmentally and socially responsible manner; and in turn, this interdependence helps companies become sustainable and resilient. Business ecosystem can be measured using the following indicators.

Table 1. Dimension and Indicator of Business Ecosystem

\begin{tabular}{lll}
\hline Dimension & \multicolumn{2}{l}{ Indicator } \\
\hline Finance & 1. & Incurring lower operating costs than competitors \\
& 2. & Conducting cost analysis \\
\hline Marketing & 3. & Creating different products \\
& 4. & Conducting market research \\
& 5. & Focusing on particular market segment \\
\hline Sales & 6. & Focusing on particular customers \\
& 7. & Focusing on particular products \\
\hline Operations & 8. & Producing products or services with efficient costs \\
& 9. & Optimizing tools and product facilitation usages \\
& 10. & Providing work equipment's which support the outcome optimization. \\
\hline
\end{tabular}

\section{Business Agility}

Business agility encompasses a range of activities undertaken by companies that create value in a volatile and unpredictable environment. These activities include systematic variations of certain processes, products, and structures. Companies need to dedicate different resources to maintain the high level of flexibility and speed required to be agile in an international context in order to be able to proactively deal with unforeseen external changes (Bouwman, Heikkilä, Heikkilä, Leopold, \& Haaker, 2018). Business agility is a meta-capability that does not only allocate sufficient resources for the development and deployment of all specific capabilities, but also remains agile by dynamically balancing those capabilities (Kurniawan, Budiastuti, Hamsal, \& Kosasih, 2020).

Business Agility is defined as the ability to reinvent or review organizations and organizational strategies dynamically with rapid changes in the external business environment (Saputra, Chumaidah, \& Aryanto, 2021). The increasing diversity and intensity of change sources and dynamism in the contemporary business environment has led to increased agility as a means to continually adapt to external threats and opportunities (Orvos, 2019). Business agility can be measured using the following indicators. 
Table 2. Dimension and Indicator of Business Agility

\begin{tabular}{lll}
\hline Dimension & Indicator \\
\hline Developing a strategic prospect & 1. & Strategic sensitivity \\
& 2. & Immediate identification of changes \\
& 3. & Selecting strategic goals \\
\hline Customer knowledge & 4. & Resource fluidity \\
5. & Process integration and Network Synchronization \\
6. & Flourishing network due to strong partners \\
7. & Customer knowledge \\
8. & Competitor's knowledge \\
\hline
\end{tabular}

Source : Li et al., (2021)

\section{Business Model Innovation}

An innovation can be successful if the creation and implementation of new processes, products, services, and methods can produce effective and efficient quality improvement results. IT-based infrastructure innovation for business agility can be carried out in the form of product innovation and marketing innovation (Pfeffer \& Salancik, 2019). Andrews \& Duff (2019) found that it is often in times of crisis that uncertainty drives innovation. This condition allows entrepreneurs to find loopholes in the chaos, create opportunities, and set about changing the status quo, and bring new standards into existence. Shakeel et al., (2020) state that business model innovation is divided into four dimensions of innovation which are product innovation, process innovation, marketing innovation, and organizational innovation, which then the researchers make 8 indicators as follows.

Table 3. Dimension and Indicator of Business Model Innovation

\begin{tabular}{|c|c|}
\hline Dimension & Indicator \\
\hline Product & $\begin{array}{ll}\text { 1. } & \text { Product Quality } \\
\text { 2. } & \text { Product Variation }\end{array}$ \\
\hline Process & $\begin{array}{l}\text { 3. New Method Usage } \\
\text { 4. New Technological Usage }\end{array}$ \\
\hline Marketing & $\begin{array}{ll}\text { 5. } & \text { Cost } \\
\text { 6. } & \text { Place } \\
\text { 7. } & \text { Promotion }\end{array}$ \\
\hline Organizational & $\begin{array}{l}\text { 8. Administrative Renewability } \\
\text { 9. Technological Renewability } \\
\text { 10. Strategy Innovation }\end{array}$ \\
\hline
\end{tabular}

Source : Shakeel et al., (2020)

\section{Government Regulation}

Regulation is an instrument for realizing state policies in order to achieve state goals (Potoski \& Prakash, 2004). As an instrument to realize every state policy, regulations must be formed in the right way so that they are able to produce good regulations, encourage the implementation of orderly social dynamics, and encourage the performance of state administration (Faisal, Situmorang, Achmad, \& Prastiwi, 2020). Changes in SMEs regulations issued can support the ease of starting a business, but these regulations will not run effectively without the support of local governments to participate in creating regulations that are in line with the central government (Ali \& Osmanaj, 2020). Government regulations are ultimately able to support corporate innovation through knowledge transfer and technological changes. In addition to having an impact on business innovation, (Bargués-Pedreny \& Mathieu, 2018) state that strategic experience occurs when mistakes are found and corrected by rethinking, regulation, and policy adjustments. This research found that the strategic learning (strategic knowledge creation, strategic knowledge distribution, strategic knowledge interpretation, and strategic knowledge implementation) has a significant impact on business agility in Elba House Company in Jordan. Regulatory dynamics are measured using the following indicators. 
Table 4. Dimension and Indicator of Regulatory Dynamics

\begin{tabular}{ll}
\hline Dimension & Indicator \\
\hline Impact (Kamran, Arshad, \& Omran, 2019) & 1. Burden of government regulations \\
& 2. Effectiveness of antitrust policy \\
\hline Obstacle & 3. Burden of government regulations \\
& 4. Extent and effect of taxation \\
& 5. Intensity of local competition \\
& 6. Prevalence of trade barriers \\
& 7. Ease of starting a new business \\
8. Stringency of environmental regulations
\end{tabular}

Source : Ali \& Osmanaj (2020)

\section{Research Method}

The research approach used in this study is a quantitative approach. Quantitative research method aims to test the established hypotheses. The quantitative method is in the form of numbers derived from measurements using a scale on the variables in the study. The population in this study were all SMEs in Bali, Bandung, Surabaya, Yogyakarta, Semarang, Solo dan Jakarta. Respondents in this study were 100 SMEs Culinary in Bali, Bandung, Surabaya, Yogyakarta, Semarang, Solo dan Jakarta. The sample is determined by a probability sample technique where the total population is not known with certainty. The data analysis uses the structural approach of the Equation Model (SEM) assisted by the smart PLS application (Sohaib, Hussain, Asif, Ahmad, \& Mazzara, 2020). The stages of data analysis in this study are described in the following.

\section{Outer Model Analysis}

1) Validity and Reliability Test

Validity and reliability tests are carried out to ensure that the measurement used is feasible to be used as a measurement (valid and reliable). Testing the validity can be seen from Convergent validity, Discriminant validity and testing the reliability can be seen from Composite reliability and Cronbach Alpha.

2) R-Square Test

$\mathrm{R}$-square for the dependent construct is used to assess the effect of certain independent latent variables on the dependent latent variable which shows the presentation of the magnitude of the effect.

\section{Inner Model Analysis}

The analysis of the inner model in testing using Smart PLS is done by testing the hypothesis. In testing the hypothesis, it can be seen from the t-statistical value and probability value. To test the hypothesis by using statistical values, thus, for alpha $5 \%$, the t-statistic value used is 1.96 . In addition, the beta score is used to determine the direction of the influence of the relationship between variables. The criteria for acceptance/rejection of the hypothesis are:

$\mathrm{Ha}=\mathrm{t}$-statistics $>1.96$ with p-values of $<0.05$

$\mathrm{H}_{0}=\mathrm{t}$-statistics $<1.96$ with p-values of $>0.05$.

\section{Result and Discussion}

\section{Outer Model Analysis}

1) Validity Test

Validity test is used to measure the validity of a questionnaire. In this research, validity testing is carried out using convergent validity and AVE. The instrument is declared valid if the AVE value is $>0.5$ and the outer loading value is $>0.7$. Based on the validity test result, it can be concluded that all indicators are valid with the outer loading value $>0.7$ and AVE value $>0.5$.

2) Reliability Test

This study uses two types of reliability tests which are Cronbach Alpha test and Composite Reliability test. Cronbach Alpha measures the lowest value (lower-bound) reliability while Composite reliability measures the actual reliability value of a variable. The data is declared reliable 
if the data has a Cronbach alpha value of $>0.7$ and declared to have high reliability if it has a composite reliability score of $>0.7$.

Table 5. Reliability Test Result

\begin{tabular}{llll}
\hline & $\begin{array}{l}\text { Cronbach } \\
\text { Alpha }\end{array}$ & $\begin{array}{l}\text { Composite } \\
\text { Reliability }\end{array}$ & Result \\
\hline Business Ecosystem (X1) & 0.922 & 0.922 & Reliable \\
\hline Business Modal Innovation (Z) & 0.910 & 0.927 & Reliable \\
\hline Government Regulation (X2) & 0.888 & 0.913 & Reliable \\
\hline Business Agility (Y) & 0.894 & 0.915 & Reliable \\
\hline
\end{tabular}

Source: Primary Data, Processed by Smart PLS, 2021

3) R-Square Test

The Coefficient Determination (R-Square) test is used in the measurement to measure how much the endogenous variable is influenced by other variables. Based on data analysis carried out using the smart PLS program, the R-Square value is obtained as shown in the following table.

Table 6. R-Square Test Result

\begin{tabular}{lll}
\hline & R-Square & Adjusted R-Square \\
\hline Business Model Innovation & 0.688 & 0.679 \\
\hline Business Agility & 0.616 & 0.608 \\
\hline \multicolumn{2}{c}{ Source: Primary Data, Processed by } & Smart PLS, 2021
\end{tabular}

Based on the test result, the R-Square score for business model innovation is 0.688 , which means that business model innovation is influenced by the business ecosystem and government regulations by $68.8 \%$ and the other $31.2 \%$ is influenced by variables that have not been explained in this study. The R-Square score for Business agility is 0.616 , which means that the business ecosystem, government regulation and business model innovation affect business agility by $61.6 \%$ and $38.4 \%$ are influenced by other variables that have not been explained in this study.

Inner Model Analysis

Table 7. Hypothesis Test Result

\begin{tabular}{|c|c|c|c|c|}
\hline Hypothesis & $\beta$ & $\begin{array}{l}\text { T- } \\
\text { Statistics }\end{array}$ & $\begin{array}{l}\text { P- } \\
\text { Values }\end{array}$ & Result \\
\hline $\begin{array}{l}\text { 1. Effect of Business Ecosystem (X1) toward Business Model Innovation } \\
\text { (Z) }\end{array}$ & 0.320 & 3.513 & 0.000 & $\begin{array}{l}\text { Positive } \\
\text { Significant }\end{array}$ \\
\hline 2. Effect of Business Ecosystem (X1) toward Business Agility (Y) & 0.257 & 2.659 & 0.008 & $\begin{array}{l}\text { Positive } \\
\text { Significant }\end{array}$ \\
\hline $\begin{array}{l}\text { 3. Effect of Government Regulation (X2) toward Business Model } \\
\text { Innovation }(\mathrm{Z})\end{array}$ & 0.517 & 5.694 & 0.000 & $\begin{array}{l}\text { Positive } \\
\text { Significant }\end{array}$ \\
\hline 4. Effect of Government Regulation (X2) toward Business Agility (Y) & 0.228 & 2.086 & 0.038 & $\begin{array}{l}\text { Positive } \\
\text { Significant }\end{array}$ \\
\hline 5. Effect of Business Model Innovation ( $\mathrm{Z}$ ) toward Business Agility (Y) & 0.427 & 4.195 & 0.000 & $\begin{array}{l}\text { Positive } \\
\text { Significant }\end{array}$ \\
\hline $\begin{array}{l}\text { 6. Effect of Business Ecosystem (X1) toward Business Agility (Y) } \\
\text { Mediated by Business Model Innovation (Z) }\end{array}$ & 0.136 & 2.490 & 0.013 & $\begin{array}{l}\text { Positive } \\
\text { Significant }\end{array}$ \\
\hline $\begin{array}{l}\text { 7. Effect of Government Regulation (X2) toward Business Agility (Y) } \\
\text { Mediated by Business Model Innovation (Z) }\end{array}$ & 0.221 & 3.406 & 0.001 & $\begin{array}{l}\text { Positive } \\
\text { Significant }\end{array}$ \\
\hline
\end{tabular}

Source: Primary Data, Processed by Smart PLS, 2021

1) Effect of Business Ecosystem (X1) toward Business Model Innovation (Z)

The result of hypothesis testing the effect of business ecosystem toward business model innovation obtained a positive beta score $(\mathrm{p}=0.320)$ with $\mathrm{p}$-values of $0.000(\mathrm{p}<0.05)$ with $\mathrm{t}$-statistic of 3.513 ( $p>1.96$ ) indicating that there is a significant and positive influence between the business ecosystem and business model innovation. Therefore, the better the business ecosystem will add to the company's business model innovation. With a business ecosystem, a company or a business running will have an impact on efficiency and effectiveness in building business relationships. A business ecosystem that can be developed is able to create mutually supportive positive relationships between 
business executants and factors in it to have a positive influence on micro and small businesses. A business ecosystem occurs between various institutional and individual stakeholders; thus, it can encourage entrepreneurship, innovation, and the growth of SMEs. The result is in accordance with research by (Antikainen \& Valkokari, 2016; Hsieh et al., 2017; Radziwon \& Bogers, 2019; Ramezani \& Camarinha-Matos, 2020).

2) Effect of Business Ecosystem (X1) toward Business Agility (Y)

The results of hypothesis testing the effect of business ecosystem toward business agility obtained a positive beta score $(\mathrm{p}=0.257)$ with $\mathrm{p}$-values of $0.008(\mathrm{p}<0.05)$ with a t-statistic of 2.659 $(p>1.96)$ indicating that there is a significant and positive effect between business ecosystem toward business agility. Therefore, the better the business ecosystem, the more the business agility of a company increase. The result is in accordance with research by(Radziwon \& Bogers, 2019) The business ecosystem approach contains a set of actors and factors that are related and coordinated both formally and informally interconnected each other, regulate, and mediate all entrepreneurial performance starting from the initial stages that produce new entrepreneurs to business development aiming to increase ability and competitiveness. A good business ecosystem is able to facilitate the growth of entrepreneurship through providing access to training, guidance, financing, and networks (Kementrian KUKM, 2021). The concept of a good business ecosystem is important to pay attention to regarding its influence on economic growth and through this concept a network system created that can regulate independently and is useful to support the existence of SMEs.

3) Effect of Government Regulation (X2) toward Business Model Innovation (Z)

The result of hypothesis testing the effect of government regulation toward business model innovation obtained a positive relationship direction with a beta score $(\mathrm{p}=0.517)$ with $\mathrm{p}$-values of $0.000(\mathrm{p}<0.05)$ and a t-statistic of $5.694(\mathrm{p}>1.96)$ indicating that the dynamics of regulation influences business models Innovation. This result is in accordance with the findings by (Glotko et al., 2020; Kaal, 2017; Louw \& Nieuwenhuizen, 2020) The government's commitment to improve the economic and investment climate is carried out by deregulating various strategic economic sectors, one of which is Micro, Small, and Medium Enterprises (SMEs). This is reflected in President Joko Widodo's directive to cut regulations in 2015. DPDRI (2009) stated "the main reason why the constitution must undergo changes is of course because the constitution is considered to have been abandoned by its era, is no longer in accordance with the needs of the people who live in it". The existing deregulation will provide ease of doing business for SMEs executants to be able to grow and contribute to the national economy. The Indonesian nation must move from regulation to implementation consistently with the intelligence to seize the opportunities that are open for public. Ease of doing business in the Job Creation Law related to the status of the Company, the Job Creation Law regulates the exception of the establishment of the Company for SMEs where for SMEs 1 (one) person can be established and its establishment is sufficient based on a statement of establishment made in Indonesian. In addition, the Job Creation Law changes the rules for the minimum authorized capital limit which now no longer has a minimum limit.

4) Effect of Government Regulation (X2) toward Business Agility (Y)

The results of hypothesis testing the effect of government regulation toward business model innovation obtained a positive beta score $(\mathrm{p}=0.228)$ with $\mathrm{p}$-values of $0.038(\mathrm{p}<0.05)$ and a t-statistic of 2.086 ( $p>1.96$ ) indicating that the dynamics of regulation influences business agility. The result is in line with the findings by (Graafland \& Bovenberg, 2020) Legislation is part of the national legal system that plays a very important role in development. The urgency of harmonizing current laws and regulations in Indonesia is becoming more significant, amidst increasingly complex situations and conditions, including the implementation of regional autonomy and the influence of globalization. The state is responsible for providing and facilitating the existence of SMEs. This convenience, as a regulator, the government issues various regulations related to the existence of SMEs. This was created in the provision of interest subsidies for both people's business loans (KUR) and non-KUR, the placement of government funds in commercial banks for credit restructuring and guarantees for SMES loans. There is also the imposition of a final SMES income tax $(\mathrm{PPh})$ borne by the government, investment financing to cooperatives through the UMKM Cooperative revolving fund management agency (LPDB-KUMKM), as well as Productive Presidential Assistance (Banpres) or assistance for micro-enterprises.

416

(C) 2021. The $5^{\text {th }}$ International Conference on Family Business and Entrepreneurship. 
5) Effect of Business Model Innovation (Z) toward Business Agility (Y)

The results of hypothesis testing the effect of business model innovation toward business agility obtained a positive beta score $(\mathrm{p}=0.427)$ with $\mathrm{p}$-values of $0.000(\mathrm{p}<0.05)$ and $\mathrm{t}$-statistic of 4.195 ( $p>1.96$ ) indicating that business model innovation influences business agility. The result is in line with the findings by (Clauss, Abebe, Tangpong, \& Hock, 2021; Hogan \& Coote, 2014) Facing changes in the fluctuating business environment due to companies must have the ability to adjust internal business resources and market behaviour. Agility is the ability of the company's business activities broadly which includes the organization's ability to manage internal factors such as structural adjustments, utilization of information systems, company logistics management, and creating employee mind-sets to be more agile in dealing with market dynamics. The main characteristic of agility is having flexible operational capabilities to be able to respond quickly to environmental changes. (Attar, Çağlıyan, \& Abdul-kareem, 2021) state that a company having agility will be able to adapt to market conditions through changes in the flow of operations or organizational structuring in order to survive. To be able to take market opportunities, companies must be agile in making every decision with actions that benefit the company.

6) Effect of Business Ecosystem (X1) toward Business Agility (Y) Mediated by Business Model Innovation $(\mathrm{Z})$

The results of hypothesis testing the effect of business ecosystem toward business agility mediated by business model innovation obtained a positive beta score $(\mathrm{p}=0.136)$ with $\mathrm{p}$-values of $0.013(\mathrm{p}<0.05)$ and a t-statistic of 2.490 ( $\mathrm{p}>1.96)$ indicating that business model innovation can mediate business ecosystem relationship to business agility. Agility is the ability to think and understand situations quickly. In business sector, agility is a method that puts projects on a smaller scale and engages team members through constant collaboration. To implement an agile process, all stakeholders must provide support because process overhaul can occur completely. A wellestablished relationship with strategic partners can enable SMEs to collaborate and innovate that can increase the target or larger market. The result is in accordance with the findings of (Carayannis, Sindakis, \& Walter, 2015; Clauss et al., 2021; Garzella, Fiorentino, Caputo, \& Lardo, 2021).

7) Effect of Government Regulation (X2) toward Business Agility (Y) Mediated by Business Model Innovation $(\mathrm{Z})$

The results of hypothesis testing the effect of government regulation toward business agility mediated by business model innovation obtained a positive beta score $(\mathrm{p}=0.221)$ with $\mathrm{p}$-values of $0.001(\mathrm{p}<0.013)$ and a t-statistic of $3.406(\mathrm{p}>1.96)$ indicating that business model innovation can mediate relationship of government regulation to business agility. Government regulations to support SMEs have been shown in various forms. The rolling out of government aid funds has become a breath of fresh air for the continued growth of small and medium-sized businesses; the government has also begun to conduct various trainings by deploying reliable and trained personnel to provide direction and guidance for entrepreneurs and the resources within them. The existence of various policies that can support SMEs through capital support and increasing SMES human resources makes SMEs able to survive in an increasingly competitive business environment where customer needs, wants, and demands are changing so that customers will not always consume the same product. The existence of strong human resources can make the company's goals quickly achieved. Expectations in meeting needs expect deeper in terms of quality, renewal, and price. Therefore, innovative skills are needed to satisfy consumers while retaining consumers as a customer. SMEs with quality human resources accompanied by capital support keep SMEs alive and well. The result is in line with the findings of (Clauss et al., 2021; Zhang, Sun, \& Lyu, 2017).

\section{Conclusion}

The result shows that the business ecosystem and government regulation and business model innovation have a significant positive effect on business agility. Business model innovation can mediate the relationship of the business ecosystem to business agility and the relationship of government regulation to business agility. Business model innovation is influenced by business ecosystem and government regulation by $68.8 \%$, business ecosystem, government regulation and business model innovation affect business agility by $61.6 \%$. Researchers who want to conduct research on the same topic can add other independent and dependent variables or use other research methods in order to obtain more coherent results. 


\section{References}

Ali, O., \& Osmanaj, V. (2020). The role of government regulations in the adoption of cloud computing: A case study of local government. Computer Law and Security Review. https://doi.org/10.1016/j.clsr.2020.105396

Andrews, G. J., \& Duff, C. (2019). Matter beginning to matter: On posthumanist understandings of the vital emergence of health. Social Science and Medicine. https://doi.org/10.1016/j.socscimed.2019.02.045

Antikainen, M., \& Valkokari, K. (2016). A Framework for Sustainable Circular Business Model Innovation. Technology Innovation Management Review. https://doi.org/10.22215/timreview1000

Attar, M., Çağliyan, V., \& Abdul-kareem, A. (2021). Evaluating the Moderating Role of Work-Life Balance on the Effect of Job Stress on Job Satisfaction. Istanbul Business Research. https://doi.org/10.26650/ibr.2020.49.0081

Bargués-Pedreny, P., \& Mathieu, X. (2018). Beyond Silence, Obstacle and Stigma: Revisiting the 'Problem' of Difference in Peacebuilding. Journal of Intervention and Statebuilding. https://doi.org/10.1080/17502977.2018.1513622

Berliandaldo, M., Fasa, A. W. H., Kholiyah, S., Chodiq, A., \& Hendrix, T. (2020). Digital Transformation and Business Development Strategy of Adaptive and Sustainable Msme Postcovid-19Pandemy. Jurnal Analis Kebijakan.

Bouwman, H., Heikkilä, J., Heikkilä, M., Leopold, C., \& Haaker, T. (2018). Achieving agility using business model stress testing. Electronic Markets. https://doi.org/10.1007/s12525-016-0243-0

Carayannis, E. G., Sindakis, S., \& Walter, C. (2015). Business Model Innovation as Lever of Organizational Sustainability. Journal of Technology Transfer. https://doi.org/10.1007/s10961-013-9330-y

Clauss, T., Abebe, M., Tangpong, C., \& Hock, M. (2021). Strategic Agility, Business Model Innovation, and Firm Performance: An Empirical Investigation. IEEE Transactions on Engineering Management. https://doi.org/10.1109/TEM.2019.2910381

Cohendet, P., Simon, L., \& Mehouachi, C. (2020). From business ecosystems to ecosystems of innovation: the case of the video game industry in Montréal. Industry and Innovation. https://doi.org/10.1080/13662716.2020.1793737

Faisal, F., Situmorang, L. S., Achmad, T., \& Prastiwi, A. (2020). The role of government regulations in enhancing corporate social responsibility disclosure and firm value. Journal of Asian Finance, Economics and Business. https://doi.org/10.13106/JAFEB.2020.VOL7.NO8.509

Ferreira, J. J., \& Teixeira, A. A. C. (2019). Open innovation and knowledge for fostering business ecosystems. Journal of Innovation and Knowledge. https://doi.org/10.1016/j.jik.2018.10.002

Garzella, S., Fiorentino, R., Caputo, A., \& Lardo, A. (2021). Business model innovation in SMEs: the role of boundaries in the digital era. Technology Analysis and Strategic Management. https://doi.org/10.1080/09537325.2020.1787374

Geissdoerfer, M., Vladimirova, D., \& Evans, S. (2018). Sustainable business model innovation: A review. Journal of Cleaner Production. https://doi.org/10.1016/j.jclepro.2018.06.240

Glotko, A. V., Polyakova, A. G., Kuznetsova, M. Y., Kovalenko, K. E., Shichiyakh, R. A., \& Melnik, M. V. (2020). Main trends of government regulation of sectoral digitalization. Entrepreneurship and Sustainability Issues. https://doi.org/10.9770/jesi.2020.7.3(48)

Graafland, J., \& Bovenberg, L. (2020). Government regulation, business leaders' motivations and environmental performance of SMEs. Journal of Environmental Planning and Management. https://doi.org/10.1080/09640568.2019.1663159

Graça, P., \& Camarinha-Matos, L. M. (2017). Performance indicators for collaborative business ecosystems - Literature review and trends. Technological Forecasting and Social Change. https://doi.org/10.1016/j.techfore.2016.10.012

Gui, A., Fernando, Y., Shaharudin, M. S., Mokhtar, M., Karmawan, I. G. M., \& Suryanto. (2020). Cloud computing adoption using toe framework for Indonesia's micro small medium enterprises. International Journal on Informatics Visualization. https://doi.org/10.30630/joiv.4.4.458

Hogan, S. J., \& Coote, L. V. (2014). Organizational culture, innovation, and performance: A test of Schein's model. Journal of Business Research. https://doi.org/10.1016/j.jbusres.2013.09.007

Hsieh, Y. C., Lin, K. Y., Lu, C., \& Rong, K. (2017). Governing a sustainable business ecosystem in Taiwan's circular economy: The story of spring pool glass. Sustainability (Switzerland). https://doi.org/10.3390/su9061068

Kaal, W. A. (2017). Private Investment Fund Regulation - Theory and Empirical Evidence from 1998 to 2016. SSRN Electronic Journal. https://doi.org/10.2139/ssrn.2998097 
Kamran, H. W., Arshad, S. B. B. M., \& Omran, A. (2019). Country governance, market concentration and financial market dynamics for banks stability in Pakistan. Research in World Economy. https://doi.org/10.5430/rwe.v10n2p136

Kementerian Koperasi dan Usaha Kecil Menengah. (2017). Perkembangan data usaha mikro, kecil, menengah (umkm) dan usaha besar (ub) tahun 2016 - 2017. Depkop.

Kementrian KUKM. (2021). Perkembangan Data Usaha Mikro, Kecil, Menengah, dan Usaha Besar. Www.Depkop.Go.Id.

Koçu, L. (2018). Business-It Alignment Effects on Business Agility. International Journal of Commerce and Finance.

Kurniawan, R., Budiastuti, D., Hamsal, M., \& Kosasih, W. (2020). Networking capability and firm performance: the mediating role of market orientation and business process agility. Journal of Business and Industrial Marketing. https://doi.org/10.1108/JBIM-01-2020-0023

Li, H., Wu, Y., Cao, D., \& Wang, Y. (2021). Organizational mindfulness towards digital transformation as a prerequisite of information processing capability to achieve market agility. Journal of Business Research. https://doi.org/10.1016/j.jbusres.2019.10.036

Lorenzo, O., Kawalek, P., \& Wharton, L. (2018). Entrepreneurial skills. In Entrepreneurship, Innovation and Technology. https://doi.org/10.4324/9781351018425-5

Louw, C., \& Nieuwenhuizen, C. (2020). Digitalisation strategies in a South African banking context: A consumer services analysis. SA Journal of Information Management. https://doi.org/10.4102/sajim.v22i1.1153

Lytvynenko, S., \& Panasiuk, I. (2020). Trends and Prospects of the Development of the Global and National Air Transport Markets. Electronic Scientific Journal Intellectualization of Logistics and Supply Chain Management \#1 2020. https://doi.org/10.46783/smart-scm/2020-1-9

Malelak, D., Kellen, P. B., \& Rozari, P. De. (2020). EFEKTIVITAS KREDIT USAHA RAKYAT DALAM PENGEMBANGAN USAHA MIKRO KECIL DAN MENENGAH. Jurnal EBI. https://doi.org/10.52061/ebi.v2i1.12

Orvos, J. (2019). Achieving Business Agility With SAFe 5.0. Scaled Agile Framework White Paper.

Pfeffer, J. ;, \& Salancik, G. (2019). Social Control of Organizations (The external control of organizations : a resource dependence perspective). Academy of Management Journal.

Potoski, M., \& Prakash, A. (2004). The Regulation Dilemma: Cooperation and Conflict in Environmental Governance. Public Administration Review. https://doi.org/10.1111/j.1540-6210.2004.00357.x

Purwaningsih, E., \& Suhaeri. (2019). Empowerment model of micro, small, and medium enterprises (Msmes) village tourism business in e-commerce transactions and legal protection. Journal of Advanced Research in Law and Economics. https://doi.org/10.14505/jarle.v10.3(41).24

Putri Rusadi, F. A. R., \& Benuf, K. (2020). Fintech peer to peer lending as a financing alternative for the development MSMEs in Indonesia. Legality: Jurnal Ilmiah Hukum. https://doi.org/10.22219/ljih.v28i2.12865

Radziwon, A., \& Bogers, M. (2019). Open innovation in SMEs: Exploring inter-organizational relationships in an ecosystem. Technological Forecasting and Social Change. https://doi.org/10.1016/j.techfore.2018.04.021

Ramezani, J., \& Camarinha-Matos, L. M. (2020). Approaches for resilience and antifragility in collaborative business ecosystems. Technological Forecasting and Social Change. https://doi.org/10.1016/j.techfore.2019.119846

Ratnawati, K. (2020). The Influence of Financial Inclusion on MSMEs' Performance Through Financial Intermediation and Access to Capital. Journal of Asian Finance, Economics and Business. https://doi.org/10.13106/jafeb.2020.vol7.no11.205

Rezac, F. (2020). Addressing conceptual randomness in iot-driven business ecosystem research. Sensors (Switzerland). https://doi.org/10.3390/s20205842

Rong, K., Lin, Y., Li, B., Burström, T., Butel, L., \& Yu, J. (2018). Business ecosystem research agenda: More dynamic, more embedded, and more internationalized. Asian Business and Management. https://doi.org/10.1057/s41291-018-0038-6

Rong, K., Patton, D., \& Chen, W. (2018). Business models dynamics and business ecosystems in the emerging 3D printing industry. Technological Forecasting and Social Change. https://doi.org/10.1016/j.techfore.2018.06.015

Saputra, N., Chumaidah, E., \& Aryanto, R. (2021). Multi-layer agility: a proposed concept of business agility in organizational behavior perspective. Diponegoro International Journal of Business. https://doi.org/10.14710/dijb.4.1.2021.30-41

419

(C) 2021. The $5^{\text {th }}$ International Conference on Family Business and Entrepreneurship. 
reSaxena, G. (2019). Multidimensional competency construct for social entrepreneurs: A logistic regression approach. Kasetsart Journal of Social Sciences. https://doi.org/10.1016/j.kjss.2017.12.013

Shakeel, J., Mardani, A., Chofreh, A. G., Goni, F. A., \& Klemeš, J. J. (2020). Anatomy of sustainable business model innovation. Journal of Cleaner Production. https://doi.org/10.1016/j.jclepro.2020.121201

Sohaib, O., Hussain, W., Asif, M., Ahmad, M., \& Mazzara, M. (2020). A PLS-SEM Neural Network Approach for Understanding Cryptocurrency Adoption. IEEE Access. https://doi.org/10.1109/ACCESS.2019.2960083

Wulansari, N. A., Ranihusna, D., \& Wijaya, A. P. (2020). The role of knowledge management in MSMEs business performance. IOP Conference Series: Earth and Environmental Science. https://doi.org/10.1088/1755-1315/485/1/012059

Yacob, S., Erida, E., Machpuddin, A., \& Alamsyah, D. P. (2021). A model for the business performance of micro, small and medium enterprises: Perspective of social commerce and the uniqueness of resource capability in Indonesia. Management Science Letters. https://doi.org/10.5267/j.msl.2020.8.025

Zhang, H., Sun, X., \& Lyu, C. (2017). Exploratory orientation, business model innovation and new venture growth. Sustainability (Switzerland). https://doi.org/10.3390/su10010056 